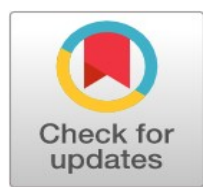

\title{
The relationships among resources' commitment reverse logistics innovation reverse logistics performance and reverse logistics cost savings: Manufacturing vs service industry
}

\author{
Burawat Piyachat * \\ Rajamangala University of Technology Thanyaburi, Pathumthani, Thailand
}

\author{
Index Terms \\ Resources' commitment \\ Reverse logistics \\ Reverse logistics innovation \\ Reverse logistics performance \\ Reverse logistics cost savings
}

Received: 6 February 2017 Accepted: 18 March 2017

Published: 30 June 2017

\begin{abstract}
The purpose of this study is to investigate the relationships among resources' commitment, reverse logistics innovation, reverse logistics performance, and reverse logistics cost savings. The study was done by means of mixed method. Regarding quantitative aspect, a survey was conducted with 403 current top and middle managers working in Thai manufacturing and service industry. The findings showed that there were positive associations between resource commitment and reverse logistics innovation, resource commitment and reverse logistics performance, reverse logistics innovation and reverse logistics performance, and reverse logistics performance and reverse logistics cost savings. The results further reported that there was a partial mediate effect of resource commitment on reverse logistics performance through reverse logistics innovation. The result further revealed that the size of company had moderate effect on model level, however, did not have moderate effect on path level. The model is different across the time of company entrance to industry and type of industry both model and path levels whereas the model is not different across length of reverse logistics implementation. However, length of reverse logistics implementation had moderation effect on path level between resource commitment and reverse logistics performance. Considering qualitative approach, the in-depth interview was conducted with 40 participants working for top and middle managers. It was found that the companies launched the reverse logistics program together with green logistics in order to enhance good company image. Firms coped with the reverse logistics program by means of reuse, recycle, repair, refurbish, scrap sale, discount and sale in outlet.
\end{abstract}

(C) 2017 The Author(s). Published by TAF Publishing.

\section{INTRODUCTION}

Presently, nearly all of the researches of supply chain management focus on the forward run which changes constituents to end products, from suppliers to final consumers (Abdullah \& Yaakub, 2014; Prahinski \& Kocabasoglu, 2006). Meanwhile, the reverse movement of material from purchasers to suppliers has got much smaller awareness (Richey, Chen, Genchev \& Daugherty, 2005; Abdullah $\&$ Yaakub, 2014). This is unfortunate in that well-organized programs of reverse logistics can diminish costs. Consistently, reverse logistics should be perceived as a chance to generate competitive advantages, diminish costs, and get better satisfaction from customers (Richey et al., 2005; Kuo \& Chen, 2015). Andel (1997) proposed that reverse logistics which are well returns managing program can evolve into a profit center. However, many organizations that formerly did not allocate much energy or time to the comprehending and management of reverse logistics, have got

\footnotetext{
* Corresponding author: Burawat Piyachat

†Email: piyachat_b@rmutt.ac.th
} 
going to spend more concentration. These organizations are comparing return systems with the company which is the best-in-class (Rogers \& Tibben-Lembke, 1998).

The projected exact cost of reverse logistics is difficult because many companies overlook and neglect it (Delany, 2000). Reverse Logistics Executive Council (2007) revealed that the market for reverse logistics in America in 2004 was roughly $\$ 58$ billion, consisting of $0.5 \%$ of the GDP of the United States. Reverse logistics cost is increasing (Dekker, Fleischmann, Inderfurth, Van \& Luk, 2004, Intan, 2016), which Rogers \& Tibben-Lembke (1998) proposed that it involves an extensive area of industries such as automotive, electronic, chemicals, publishing, petroleum, garments, and food and beverage industry as well as service industry. In addition, Rogers \& Tibben-Lembke (1998) reported that the reverse logistics cost accounted for 4 percent of entire logistics cost.

This is consistent with the findings of Japan Institute of Logistics Systems (JILS), which revealed that in 2004 the reverse logistics cost in Thailand accounted for 3.5\% (42 billion Baht) of total logistics cost (1,193 billion Baht), whereas the total logistics cost accounted for $16.8 \%$ of the country's GDP (7,103 billion Baht) (Banomyong, Varadejsatitwong \& Prakorbkij, 2005). According to fierce competition, companies need to improve productivity as well as reduce cost. Based on the above mentioned statistics, reverse logistics cost is high-value and worth paying more attention.

Recently, both practitioners and researchers are escalating the extent of attentiveness in reverse logistics. However, the studies of antecedents and consequences of reverse logistics are scarce (Veerakachen, 2006). Considering the antecedent factors, some studies supported the direct effect of resource commitment including technology, management, and financial resource commitment on performance of reverse logistics (Daugherty, Autry \& Ellinger, 2001; Jack, Powers \& Skinner, 2010; Alshannag, Basah \& Khairi, 2017).

However, some studies opposed that the resource commitment was not directly associated with reverse logistics performance but there was a moderate effect via length of reverse logistics adoption, reverse logistics innovation, information system, internet integration, external factors, business strategy, and independent return policy (Richey et al. . 2005; Veerakachen, 2006; Pfohl, Bode \& Nguyen, 2012). Richey et al. (2005) contended that reverse logistics innovation is associated with performance of reverse logistics in both economic and operational dimension. In addition, Huang \& Yang (2014) supported this relationship and further explained that there is a moderate effect via legal pressure, competitors, and customers. On the other hand, many studies on consequences of reverse logistics focused on cost savings and firm's performance (Daugherty et al., 2001; Jack et al., 2010; Pfohl et al., 2012; Abdullah \& Yaakub, 2014; Ramírez \& Morales, 2014). According to the lack of studies on reverse logistics, some studies confirmed that the reverse logistics innovation and resources' commitment are antecedents of reverse logistics performance, while some studies presented that the cost savings is consequence of reverse logistics performance. Although some studies presented direct relationship between antecedents and consequences of reverse logistics; however, the studies which revealed the simultaneous associations are scarce especially the concurrent relationships among resources' commitment, reverse logistics innovation, reverse logistics performance, and reverse logistics cost savings. Moreover, there are few studies interested in the moderate and mediate effect.

In conclusion, according to reverse logistics cost is highvalue and worth paying more attention as well as scarce of studies; thus, this study is partly responsible for the literature of reverse logistics by investigating the simultaneous associations among resources' commitment, reverse logistics innovation, reverse logistics performance, and reverse logistics cost savings; mediate effect of reverse logistics innovation; and moderate effect of size of company, time of company entrance to industry, type of industry, and length of reverse logistics implementation.

This study contains eleven research questions: (1) Is there a relationship between resource commitment and reverse logistics innovation? (2) Is there a relationship between resource commitment and reverse logistics performance? (3) Is there a relationship between resource commitment and reverse logistics cost savings? (4) Is there a relationship between reverse logistics innovation and reverse logistics performance? (5) Is there a relationship between reverse logistics innovation and reverse logistics cost savings? (6) Is there a relationship between reverse logistics performance and reverse logistics cost savings? (7) Is there a mediate effect of reverse logistics innovation on the relationship between resource commitment and reverse logistics performance? (8) Is there a moderate effect of size of company? (9) Is there a moderate effect of time of company entrance to industry?, (10) Is there a moderate effect of type of industry?, and (11) Is there a moderate effect of length of reverse logistics implementation? 


\section{LITERAT URE REVIEW}

Nowadays, companies struggle with fierce competition which is difficult to succeed by only one way of increasing orders to gain profit while the other important alternative is reducing costs. This is due to the fact that the total logistics cost is high proportion of total cost. Efficient reverse logistics management can reduce $10 \%$ of total logistics cost (Minahan, 1998), increase customer satisfaction, good image, and profitability (Daugherty et al., 2001). Thus, organizations need to pay more attention to reverse logistics and relevant areas to get a competitive advantage.

\section{Reverse Logistics}

Logistics was explained as the process of preparation, executing, and harnessing the well-organized, raw materials' flow with lower cost, less quantity of inventory both work in process and finished goods inventory, and linked information from the beginning point to the utilization point for the objective of complying with requirements of end users.

In contrast, reverse logistics include whole of the activities that are ascribed in the above description, which operate backwards. Thus, reverse logistics is described as the process of preparation, executing, and harnessing the wellorganized, raw materials' flow with lower cost, less quantity of inventory both work in process and finished goods inventory, and linked information from the beginning point to the utilization point for the objective of reacquiring value or appropriate elimination (Council of Logistics Management, 1997). The current research defined that reverse logistics involve return of product, source depletion, recycling, material interchange, reuse of material, waste elimination, refurbishing, amending, and reproducing (Kumar \& Ya maoka, 2007). Meanwhile, reverse logistics process can be separated into two widespread domains, i.e. return of primary products and primary packing.

Considering the primary products, the activities of reverse logistics program consists of send backwards to supplier, sell through outlet, resell, overhaul, repair, salvage, repair, renovate, reproduce, claim back materials, reuse, and landfill. In contrast, the primary packing, the activities of reverse logistics program consist of recycle, refurbish, claim back materials, reuse, and salvage (Shear, Speh \& Stock, 2002; Wu, 2016). The importance and influence of reverse logistics vary by manufacturing and service sectors as well as channel positions, e.g. the automobile companies, electronic products, publishing, garments, and retailing companies.

\section{Resource Commitment}

Resource commitment is associated with allocation of company's resource, both tangible and intangible, in order to improve productivity, meet customers' need, and increase market share (Hunt, 2000). Resource commitment consists of three aspects including managerial, financial, and technology resource commitment (Richey \& Wheeler, 2004; Chau \& Hu, 2001).

First, managerial resource commitment refers to allocation of talented, skilled, and expert human resources to create and managed strategy. Second, financial resource commitment is associated with the financial allocation to cover the costs of operation. Finally, technology resource commitment refers to technology and information system allocation which can bring about a sustainable competitive advantage since technological capabilities are difficult to imitate (Daugherty et al., 2001). Richey et al. (2005), consistent with Rogers \& Tibben-Lembke (1998), suggested that a major obstacle to a successful application of reverse logistics is insufficient resource commitment.

\section{Reverse Logistics Innovation}

Reverse logistics innovation is defined as a company's capability to search for imaginative, creative, fresh or unconventional notions, deportments, goods and processes in completing reverse logistics activities to decrease environmental responsibilities and enhance prolonged development (Rennings, 2000; Christmann, 2000; Hart, 2005; Naqshbandi \& Kaur, 2014).

In addition, the sustainability initiative capabilities of reverse logistics are often mentioned as reverse logistics innovation. Richey et al. (2005) proposed that the reverse logistics innovations are composed of five components, i.e. customization, formalization, flexibility, informationrelated ability, and cross-functional integration. First, customization is explained as the act of tailoring the goods of technology to the extraordinary and specific requirements of the end user. Second, formalization is the extent of firm's standard rules, procedures, instructions, and communications (Pugh, Hickson, Hinings \& Turner, 1968; Naqshbandi, Kaur \& Ma, 2015).

Third, flexibility is the level to which one member would like to modify or adjust to facilitate an organization member's requirements (Cannon \& Homburg, 2001). Next, information-related ability is the assessment of connectivity, usefulness, accuracy, and availability of information. Finally, cross-functional integration involves the scale of 
interaction and transmission, the extent of sharing in information, the scale of coordination and the degree of joint participation across operations during an extra return task. Although it is widely accepted that effective reverse logistics innovation can enhance fanciness and pleasure of purchasers (Richey et al., 2005; Li \& Olorunniwo, 2008; Naqshbandi \& Kaur, 2011a) and lead to saving their cost (Srivastava \& Srivastava, 2006; Jack et al., 2010), the impact of reverse logistics is often ignored and not well understood by many firms.

\section{Reverse Logistics Performance}

Conventionally, a company performance has been observed and assessed in accounting words (Conant, Mokwa \& Varadarajan, 1990; Jennings \& Seaman, 1994). However, a literature concerning with assessment of organizational performance (Kaplan \& Norton, 2001; Otley, 1999; Lynch \& Cross, 1991; Naqshbandi \& Kaur, 2011b) proposed that managers prefer to locate relatively less importance on traditional financial performance's assessments, i.e. net profits, Return On Assets (ROA), and Return On Investments (ROI). It is consistent with Barros \& Santos (2006), who proposed that firm's performance is an outcome from the ability to use resources and CEO cares for overall result of both finance and non-finance performance.

In general, the word performance results in the leading position of assessments, for example; market share, cost, and profit (Laitinen, 2002). Meanwhile, Sink \& Tuttle (1989) asserted that performance should not be dealt barely as a monetary perspective. In addition, $\mathrm{Li}$, Zhang, Zhang, Dai \& Yu (2009) suggested that performance can be evaluated by non-financial performance such as efficiency, growth, and profit. Reverse logistics performance can be measured by two familiar dimensions including economic and environmental performance. Economic performance refers to operational efficiency and effectiveness, financial performance, customer responsiveness and satisfaction. Meanwhile, environmental performance is associated with creative effective process and recognition of the supply chain partnerships, transcend the strict rules, protection of the environment, and reducing pollution (Judge \& Doughlas, 1998; Autry, Daugherty \& Richey, 2001; Daugherty, Myers \& Richey, 2002; Richey et al., 2005; Sarkis, Helms \& Hervani, 2010; Huang \& Yang, 2014; Naqshbandi \& Kaur, 2015).

\section{Reverse Logistics Cost Savings}

The structure of forward and reverse logistics is the same,

ISSN: 2414-309X

DOI: 10.20474 /jabs-3.3.2 including cost of transportation, holding, stealing, obsolete, collecting, sorting, analyzing, managing, refurbishing, repackaging, and changing in book value. However, the proportion of each cost for forward and reverse logistics is different. Considering reverse logistics cost, the transportation cost is important as collecting small and uncertain quantity of the return products results in high amount of total reverse logistics cost. Meanwhile, the holding cost and stealing cost are low whereas obsolete, collecting, sorting, analyzing, managing, refurbishing, and repackaging costs are high. Companies may apply the policy of recovered or reused raw materials or packaging materials in order to reduce costs and enhance the business image. Companies that effectively cope with the returned product such as customer's independent returned product policy will be able to respond quickly, increase satisfaction and lead to higher profitability (Dawe, 1995).

\section{Theoretical Framework}

The proposed theoretical model is to investigate the simultaneous associations among resources' commitment, reverse logistics innovation, reverse logistics performance, and reverse logistics cost savings.

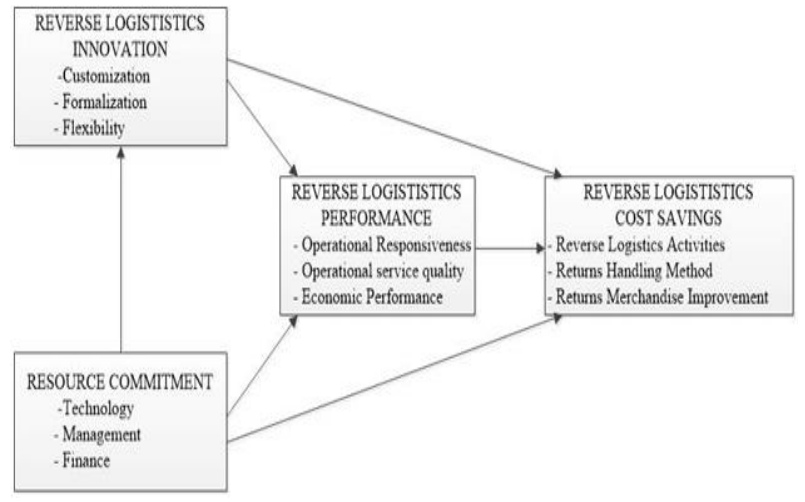

FIGURE 1. The proposed theoretical model

\section{RESEARCH METHODOLOGY} Sample and Procedure

The population for the study consists of top management and middle management executives of companies operating in both service and manufacturing industry in Thailand. Free parameter is not constrained and is to be estimated by using observed data (Weston \& Gore, 2006; Hair, Anderson, Tatham \& Black, 1998). Considering theory of normal distribution, Bentler \& Chou (1987) and Bentler (1989) stated that in order to receive trustworthy parameter estimate, the proportion of sample size to amount of free parameters should be at least 5:1 whereas a proportion of 
10:1 would be suggested to receive appropriate significance examinations. The number of free parameters equals 35 ; therefore, in order to receive the appropriate significance investigations, the minimum sample size is 350 . A total of 403 samples (201 respondents from manufacturing industry, 202 respondents from service industry) were collected from August to November, 2016 by using simple random sampling, in which the top management and middle management managers were contacted and were provided with the letters authorized by the university to ask permissions to send the paper or online survey.

On the other hand, qualitative approach was conducted by in-depth interview from 40 top management and middle management managers (20 participants from manufacturing industry and 20 participants from service industry).

\section{Instruments}

The study design is a mixed method. Quantitative method was conducted by applying questionnaires composed of five parts. First part is demographic information of respondents. Closed-end questionnaire with 5 Likert rating scale $(1=$ no extent; 2 = little extent; 3 = some extent; 4 = extensive extent; and 5 = great extent) was used to evaluate the latter four parts.

Second, Resource Commitment (RC) was developed by Richey et al. (2005) at 0.870 alpha scales. Third, Reverse Logistics Innovation (RLI) survey was developed by Richey et al. (2005) at 0.817 alpha scales. Next, Reverse Logistics Performance (RLP) was developed by Richey et al. (2005) separated into three aspects including Operational Responsiveness (RLPOR), Operational Service Quality (RLPOSQ), and Economic Performance (RLPEP) dimension at 0.816, 0.781 and 0.890 alpha scales. Last, Reverse Logistics Cost Savings (RLCS) was developed by Jack et al. (2010) at 0.893 alpha scale. In contrast, qualitative data were done by indepth interview applying semi-structure open-ended questionnaire composed of current situation of companies' re- verse logistics efficiency, overview, recommendations, and expected results of reverse logistics implementation.

\section{Structural Equation Model (SEM)}

Wright (1921) explained that the structural equation model (SEM) is a technique of statistics for investigating and forecasting rational association applying an integration of statistical data and qualitative rational ascriptions. This study is comprehensive by the following eleven hypotheses:

HI: There is a positive association between resource commitment and reverse logistics innovation.

H2: There is a positive association between resource commitment and reverse logistics performance.

H3: There is a positive association between resource commitment and reverse logistics cost savings.

H4: There is a positive association between reverse logistics innovation and reverse logistics performance.

H5: There is a positive association between reverse logistics innovation and reverse logistics cost savings.

H6: There is a positive association between reverse logistics performance and reverse logistics cost savings.

H7: There is a mediate effect of resource commitment on reverse logistics performance through reverse logistics innovation.

H8: There is a moderate effect of size of company on the simultaneous relationships of the proposed theoretical model.

H9: There is a moderate effect of time of company entrance to industry on the simultaneous relationships of the proposed theoretical model.

H10: There is a moderate effect of type of industry on the simultaneous relationships of proposed theoretical model.

H11: There is a moderate effect of length of reverse logistics implementation on the simultaneous relationships of proposed theoretical model. 
TABLE 1 . The minimum criterion of model fit indices

\begin{tabular}{cl}
\hline \hline Model Fit Index & Threshold/Minimum Criterion \\
\hline$X^{2}$ or CIMN & -should not be significant at a 0.05 threshold (I=p>0.05) (Hu \& Bentler, 1999) \\
$X^{2} / \mathrm{df}$ or CIMN/df & -should be less than 5.0 to judge the fitness of the model (Bentler, 1989) \\
CFI & -should be greater than 0.9 to judge the good fit (Bentler \& Bonett, 1980) \\
IFI & -should be greater than 0.9 to judge the good fit (Bentler \& Bonett, 1980) \\
& -should be greater than 0.9 to judge the good fit (Joreskog \& Sorbom, 1996) \\
AGFI & -AGFI of 0.8 is sometimes proposed as sufficient as recommended cut-off (Chau \& Hu, 2011) \\
PGFI & -should be greater than 0.5 to judge acceptable fit (Hair et al., 1998) \\
RMSEA & -should be less than 0.05 to judge good fit and between 0.05 and 0.08 to judge reasonable fit \\
& (Browne \& Cudeck, 1993) \\
\hline \hline Source: Piyachat, Chanongkorn \& Panisa (2014)
\end{tabular}

To measure the suitable research model associated with seven indices presented in Table 1, the correlations among variables were measured by t-test associated with $p$-value and Critical Ratios (C.R).

\section{RESULT S}

\section{Quantitative Results}

The completed 403 of 900 questionnaires (response rate $44.78 \%$ ) were used to do analysis. The larger of the respondents were female which accounted for $60.5 \%$ with age below 30 years old accounting for $51.9 \%$. The educational degree was mostly Bachelor's degree which accounted for $85.1 \%$. In addition, the respondents working in service industry accounted for $50.1 \%$, working for small and medium companies for $52.4 \%$, and working in company without union for $64.5 \%$.

Besides, the length of reverse logistics implementation between 1 and 3 years accounted for 70.0\%. Decarlo (1997) suggested that in order to assess the normal distribution, the skewness and kurtosis value should range from -3 to +3 (Stuart \& Ord, 1994). The results indicated the values of skewness range from -0.392 to 0.032 and the sizes of kurtosis range from -0.972 to 0.075 . Meanwhile, the Pearson's bivariate correlations of all relationships were significant. Therefore, it could be summarized that the normal distribution rule and linearity were asserted. Considering an overview, respondents evaluated all factors, i.e. resource commitment, reverse logistics innovation, reverse performance, and reverse logistics cost savings, at some extent corresponding with the evaluation from service and manufacturing industry.

\section{Model Fit and Hypothesis Testing}

The Chi-square is essential statistic. However, Bentler \& Bonnet (1980) and Hu \& Bentler (1999) are consistent with Jöreskog \& Sörbom (1996) who proposed that a statistical significance examination is responsive to sample size, which implies that when a huge sample size is used, the Chi-square statistic almost all the time refuses the model. Therefore, some researchers demonstrated that a model could also be admitted if most of the criteria of fit present satisfied adoption measures and only small number of fit indices are lower than the desired criterion (Bagozzi \& Yi, 1988; Fornell \& Larcker, 1981). Even though the Chisquare statistic of the proposed theoretical model offered a result at level of 0.05 significance, the other existing findings were greater than the lowest threshold presented in table 2 . Therefore, it could be summarized that the structure of resource commitment, reverse logistics innovation, reverse logistics performance, and reverse logistics cost savings were appropriate to describe the simultaneous relationships among questions and latent factors.

TABLE 2 . Model fit indices of the proposed theoretical model

\begin{tabular}{llllllllllllll}
\hline \hline CMIN & $\boldsymbol{p}$-Value & df & CMIN/df & CFI & IFI & NFI & TLI & AGFI & PGFI & RMSEA & AIC (Default Model) & BCC (Saturated Model) & BIC (Independence Model) \\
\hline 153.863 & 0.000 & 55 & 2.798 & 0.982 & 0.983 & 0.973 & 0.975 & 0.910 & 0.571 & 0.067 & 225.863 & 228.461 & 369.824 \\
\hline \hline
\end{tabular}

After model fit was assessed, the hypothesis was tested, starting with test of significance of regression weight. Considering overall group, most of the p-values of regression weights are lower than 0.05 , except that the effect of resource commitment and reverse logistics innovation on re- verse logistics cost savings is above 0.05 . The findings are consistent with both manufacturing and service industry group.

Thus, it can be concluded that $\mathrm{H} 1, \mathrm{H} 2, \mathrm{H} 4$, and $\mathrm{H} 6$ are supported whereas $\mathrm{H} 3$ and $\mathrm{H} 5$ are rejected. Then both of 
them were deleted from the structural model. The revised model is presented in figure 2 and 3 . The findings of model fit testing of the revised proposed model are shown in table 3. Although the Chi-square statistic provides outcome at level of 0.05 significance, the other existing findings are greater than the lowest threshold. Therefore, it could be summarized that the revised proposed theoretical model

is appropriate to describe the simultaneous associations among questions and latent factors.

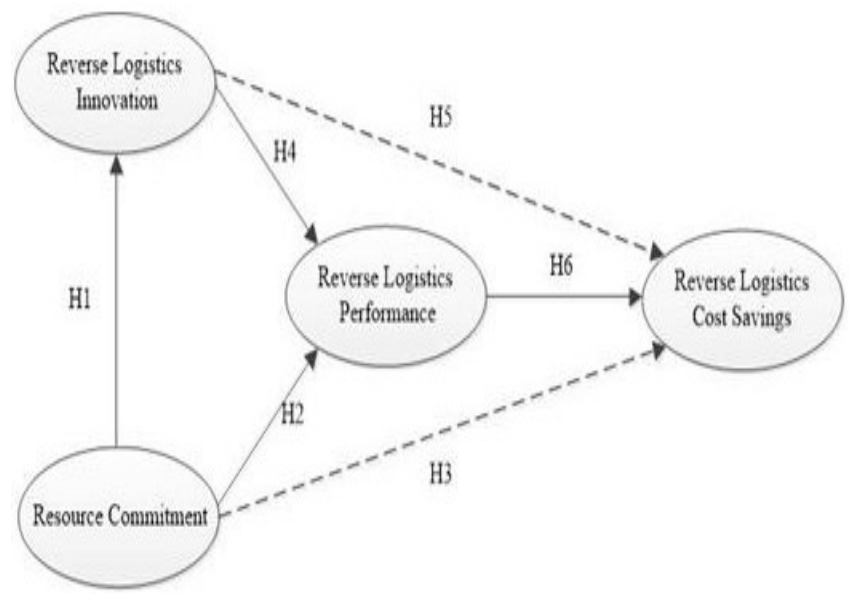

FIGURE 2 . Results of test of significance of regression weight for the proposed theoretical model

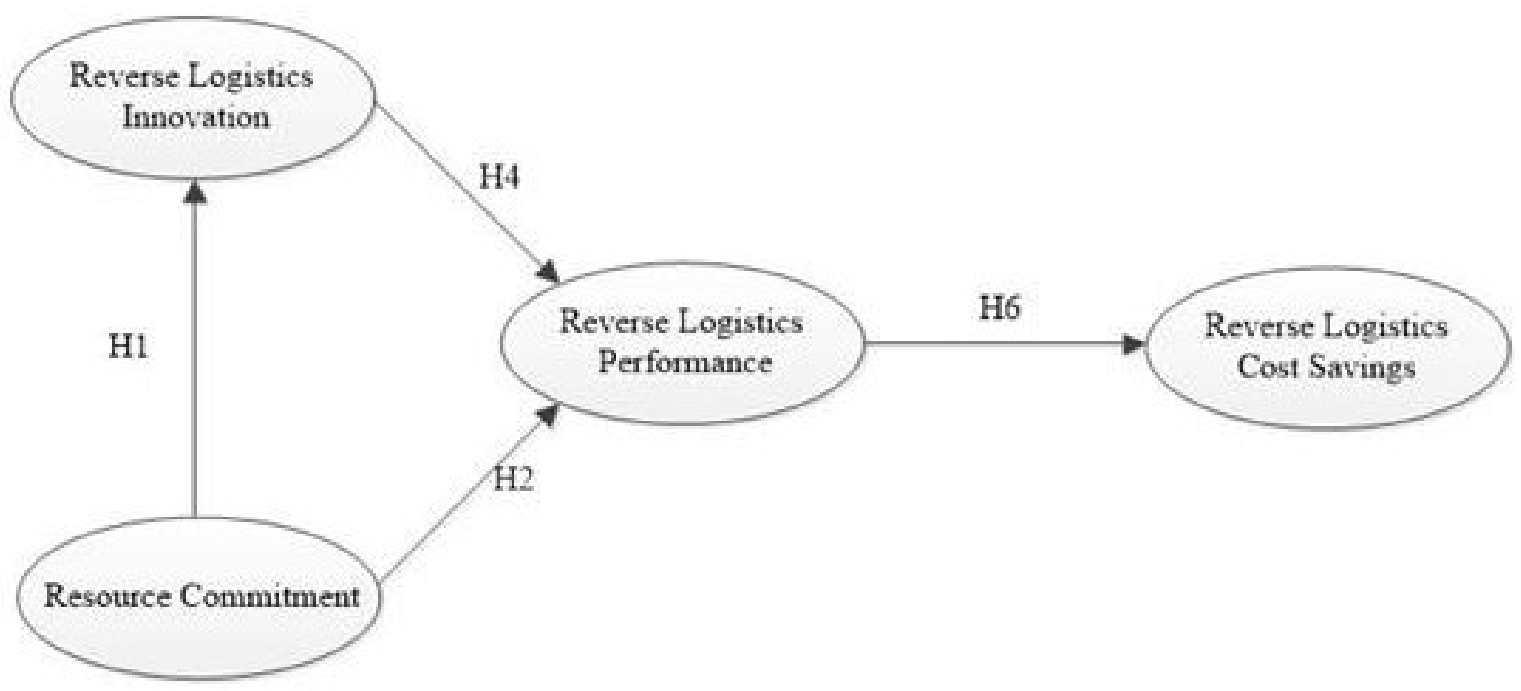

FIGURE 3 . Revised proposed theoretical model

TABLE 3 . Model fit indices of the revised proposed theoretical model

\begin{tabular}{|c|c|c|c|c|c|c|c|c|c|c|c|c|c|}
\hline CMIN & $p$-Value & df & CMIN/df & CFI & IFI & NFI & TLI & AGFI & PGFI & RMSEA & AIC (Default Model) & BCC (Saturated Model) & BIC (Independence Model) \\
\hline 154.234 & 0.000 & 57 & 2.706 & 0.985 & 0.985 & 0.973 & 0.976 & 0.913 & 0.592 & 0.067 & 222.234 & 224.687 & 358.198 \\
\hline
\end{tabular}

\section{Mediate Effect Testing}

The competing model was to examine the direct effect of resource commitment on reverse logistics innovation and reverse logistics performance, and the direct effect of reverse logistics performance on reverse logistics cost savings, which are presented in figure 4.

Comparing the model fit statistics of the competing model (Table 4) and the revised proposed theoretical model ISSN: 2414-309X

DOI: $10.20474 /$ jabs-3.3.2
(Table 3), these findings showed that the revised proposed theoretical model has higher model fit statistics than the competing model. Therefore, it could be summarized that the associations among resource commitment, reverse logistics performance, and reverse logistics cost savings are better described by an influence of resource commitment on reverse logistics performance via reverse logistics innovation.

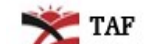




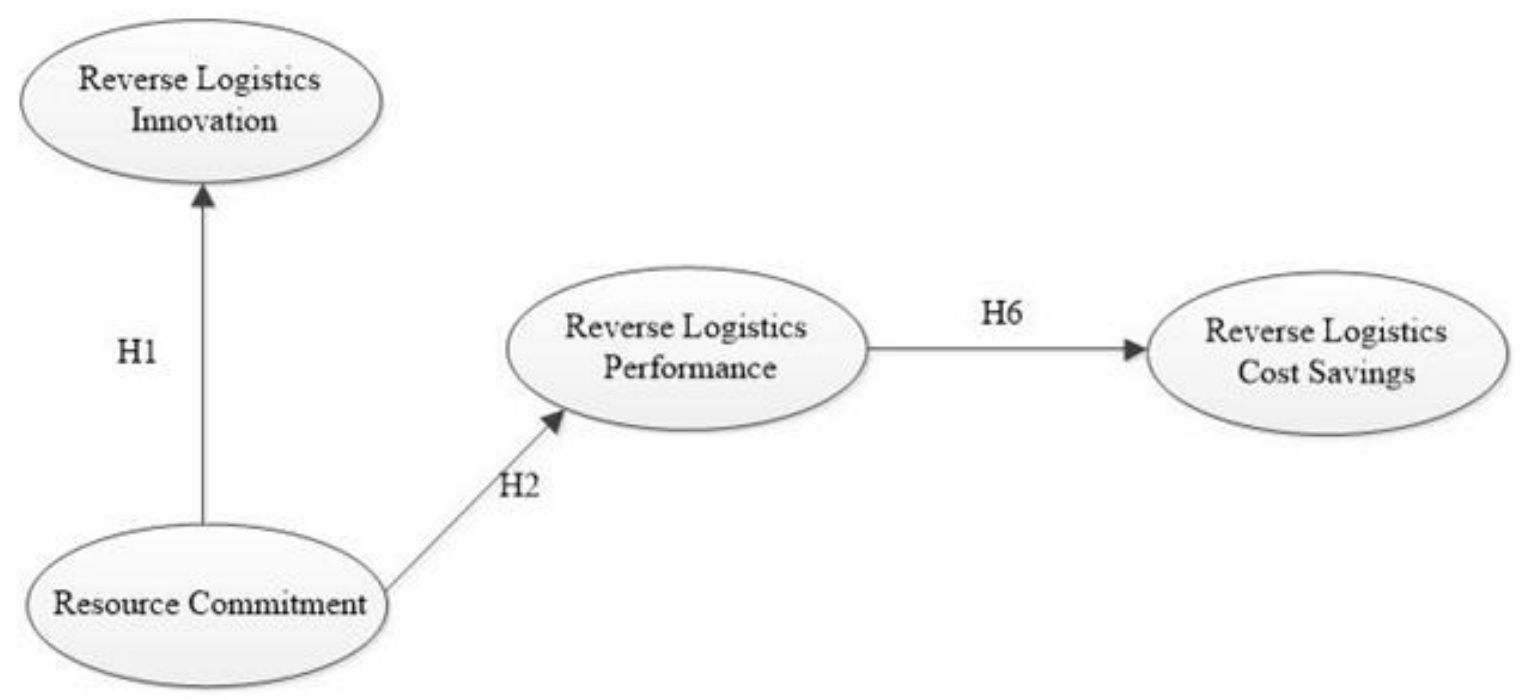

FIGURE 4 .Competing model

TABLE 4. Model fit indices of the competing model

\begin{tabular}{|c|c|c|c|c|c|c|c|c|c|c|c|c|c|}
\hline CMIN & $p$-Value & df & CMIN/df & CFI & IFI & NFI & TLI & AGFI & PGFI & RMSEA & AIC (Default Model) & BCC (Saturated Model) & BIC (Independence Model) \\
\hline 213.982 & 0.000 & 58 & 3.689 & 0.972 & 0.950 & 0.963 & 0.963 & 0.885 & 0.590 & 0.082 & 279.928 & 282.364 & 411.947 \\
\hline
\end{tabular}

Considering the competing model, the standardized direct effect between resource commitment and reverse logistics performance is 0.792 . On the other hand, the outcomes from the revised proposed theoretical model indicated that the standardized direct effect between resource commitment and reverse logistics performance is 0.0 .261 whereas the standardized indirect effect is 0.517 , and standardized total effect is 0.778 . Since the revised proposed theoretical model possessed lower value of the standardized direct effect than that of the competing model. Thus, it could be summarized that there is a partly mediate effect of resource commitment on reverse logistics performance via reverse logistics innovation. According to the greater model fit statistics and the lower degree of the standardized direct effect, it could be summarized that $\mathrm{H} 7$ is accepted.

TABLE 5 . Hypotheses testing of the revised proposed theoretical framework

\begin{tabular}{|c|c|c|c|c|c|}
\hline & & Estimate & S.E & C.R & $p$-vale \\
\hline H1: Resource commitment $\rightarrow$ & Reverse logistics innovation & 0.908 & 0.037 & 24.229 & $* * *$ \\
\hline H2: Resource commitment $\rightarrow$ & Reverse logistics performance & 0.164 & 0.047 & 3.456 & $* * *$ \\
\hline H4: Reverse logistics innovation $\rightarrow$ & Reverse logistics performance & 0.359 & 0.049 & 7.382 & $* * *$ \\
\hline H6: Reverse logistics performance $\rightarrow$ & Reverse logistics cost savings & 1.271 & 0.078 & 16.325 & $* * *$ \\
\hline
\end{tabular}

TABLE 6 . Hypotheses testing of the revised proposed theoretical framework

\begin{tabular}{|c|c|c|c|c|}
\hline & & Standardized Direct Effect & Standardized Indirect Effect & Standardized total Effect \\
\hline H1: Resource commitment $\rightarrow$ & Reverse logistics innovation & 0.862 & 0.000 & 0.862 \\
\hline H2: Resource commitment $\rightarrow$ & Reverse logistics performance & 0.261 & 0.517 & 0.778 \\
\hline H4: Reverse logistics innovation $\rightarrow$ & Reverse logistics performance & 0.600 & 0.000 & 0.600 \\
\hline H6: Reverse logistics performance $\rightarrow$ & Reverse logistics cost savings & 0.946 & 0.000 & 0.946 \\
\hline
\end{tabular}


Regarding the results in table 6, the equations for the revised proposed theoretical model were conducted.

$\mathrm{Z} R \hat{L} I=0.862 \mathrm{RC}$

$\mathrm{Z} R \hat{L C} S=0.946 \mathrm{RLI}$

$\mathrm{Z} R \hat{L} P=0.778 \mathrm{RC}+0.600 \mathrm{RLI}$

\section{Moderate Effect Testing}

Considering the moderate effect of size of company, the Chi-square of the unconstrained was 313.553 and degree of freedom equal to 114 whereas the Chi-square of the fully constrained was 343.116 and degree of freedom equal to 127. The difference of the Chi-square was 29.607 and freedom degree was equal to 13 . The p-value is 0.000 which can be concluded that the simultaneous relationships of the proposed structural model are different across size of company. After checking each specific path, the results reported that size of company did not have moderate effect on the path relations. Thus, it can be concluded that H8 is supported. Regarding the moderate effect of time of company entrance to industry, the Chi-square of the unconstrained was 397.447 and degree of freedom equal to 171 whereas the Chi-square of the fully constrained was 456.913 and degree of freedom equal to 197. The difference of the Chisquare was 59.466 and degree of freedom equal to 26 . The p-value is 0.005 which can be concluded that the simultaneous relationships of the proposed structural model are different across time of company entrance to industry.

After checking each specific path, the results reported that time of company entrance to industry had moderate effect on all path levels. Thus, it can be concluded that H9 is fully supported. Meanwhile the moderate effect of manufacturing and service industry, the Chi-square of the unconstrained was 289.419 and degree of freedom equal to 114 whereas the Chi-square of the fully constrained was 332.344 and degree of freedom equal to 127 . The difference of the Chi-square was 42.925 and freedom degree was equal to 13 . The $p$-value is 0.000 which can be concluded that the model is different across type of industry. After checking each specific path, the results reported that type of industry has moderate effect on the path level between resource commitment and reverse logistics performance at $99 \%$ confidence. Thus, it can be concluded that $\mathrm{H} 10$ is partly supported.

Considering the moderate effect of length of reverse logistics implementation, the Chi-square of the unconstrained was 299.215 and degree of freedom equal to 114 whereas the Chi-square of the fully constrained was 314.840 and degree of freedom equal to 127 . The difference of the Chi- square was 15.625 and freedom degree was equal to 13. The p-value is 0.270 which can be concluded that the model is not different across length of reverse logistics implementation. However, length of reverse logistics implementation had moderation effect on path level between resource commitment and reverse logistics performance. Thus, it can be concluded that $\mathrm{H} 11$ is rejected.

\section{Qualitative Results}

Regarding the results from in-depth interview from manufacturing industry, the participants proposed that the reverse logistics program was done to some extent since the reverse logistics management cost was inconsistent and very high compared to the cost of producing new products both in terms of money and time consumption. Furthermore, the companies decided to launch the reverse logistics program together with green logistics in order to enhance good company image.

Returned materials and packaging were coped by reuse, recycle, and scrap sale. In addition, returned work in process inventory and products were managed by repair and refurbish. In case of not worth to repair or refurbish, managers would negotiate with customers to discount or send to outlet store. Regarding large companies which have many suppliers, they will apply milk-run to reduce both forward and reverse transportation cost. Moreover, food and beverage industry handles the abundant or waste raw materials by producing other products or animal feed. On the other hand, participants from trading, store, and restaurant proposed that because customers' satisfaction is most important, thus in case of returned products, they decided to change new product for them. Defective products were discount or sale in outlet. Participants working for governmental university proposed that most of returned products were books and formal documents. Books would be donated or sent to the branch requiring these books while documents were reused and then destroyed as some of the information is confidential. Accordingly, logistics companies will manage routes which will carry full loads both depart and return transportation.

\section{DISCUSSION}

\section{Hypothesis 1}

The finding revealed that there is a positive association between resource commitment and reverse logistics innovation which confirmed the findings of the preceding researches. For instance, the study of Richey et al. (2004) and Daugherty et al. (2001). The company provides good 
resource including technological and financial support as well as good coach and advice will provide an opportunity for employees to express diverse and valuable opinions or ideas which can lead to reverse logistics innovation resulting in high competitive advantage (Hunt \& Morgan, 1996).

\section{Hypothesis 2}

The finding indicated that there is a positive association between resource commitment and reverse logistics performance, which confirms the outcomes of the prior investigations, for instance, the examination of Jack et al. (2010), Richey et al. (2004), and Daugherty et al. (2001). The company provides good resource including technological and financial support, and the good coach and advice will increase confidence of employees, not worrying about their work, daring to make decision, suggestions, and actively participating in organization's activity. This turns to higher reverse logistics performance.

\section{Hypothesis 3}

The finding presented that there is not a connection between resource commitment and reverse logistics cost savings, which is opposed to the findings of the previous studies such as Abdullah \& Yaakub (2014), and Raminez \& Morales (2014). This is because there is less strictness of enforced laws related to return and destroy the products in Thailand, unlike developed countries. The cost savings are concerning with reverse logistics consisting of product, remanufacturing, and transportation, which is low level compared to resource allocation.

\section{Hypothesis 4}

The outcome revealed that there is a positive association between resource logistics innovation and reverse logistics performance, which confirms the findings of the prior examinations, for instance, the study of Richey et al. (2005) and Huang \& Yang (2014). Innovation is hard to create and imitate, which makes different from rivals, resulting in higher performance.

\section{Hypothesis 5}

The result reported that there is not a connection between reverse logistics innovation and reverse logistics cost savings, which is opposed to the findings of the previous studies such as the study of Huang \& Yang (2014). Investment in reverse logistics innovation requires a lot of money and resources while cost savings are low; thus, the managers evaluated that there is not worth to invest.

\section{Hypothesis 6}

The outcome presented that there is a positive association between reverse logistics performance and reverse logistics cost savings, which asserts the results of the preceding investigations such as Jack et al. (2010). The company running an efficient business will use fewer resources and inputs than the standard or than competitors, which is possible to reduce costs more than low level efficient firms.

\section{Hypothesis 7}

The result reported that there is a partly mediate effect of resource commitment on reverse logistics performance through reverse logistics innovation. Reverse logistics innovation can make company different from rivals. Due to these differentiations, customers judge company better than competitors. The employees work with confidence, resulting in higher reverse logistics performance and sale volume.

\section{Hypothesis 8}

The result presented that the size of company has moderate effect on the simultaneous relationships of the proposed structural model. This is consistent with Goodman \& Abernathy (1978) and Ettlie (1983) proposed that the small and medium companies are more innovative because they can reciprocate more simply to the changings and requirements of the market, appeal adolescent, more growth-oriented personnel who may provoke innovation, and often initially determine themselves as a differentiator via product innovation.

\section{Hypothesis 9}

The result reported that the time of company entrance to industry had moderate effect on both simultaneous relationships of the proposed structural model and all path relations. The companies that lately enter the industry will apply resources to get more innovation than middle and early entrance. Early entrance will harvest the benefits of innovation that they invest before the competitors lead to higher performance than the rivals. Meanwhile, middle entrance will pay more attention on their performance and minimize cost than the others.

\section{Hypothesis 10}

The result presented that the type of industry has moderate effect on the path from resource commitment to reverse logistics performance, and the path from reverse logistics 
innovation to reverse logistics performance. Accordingly, there is difference of resource of manufacturing compared to service industry.

Thus, the suitable allocation and the providing resource are different. Regarding reverse logistics innovation, manufacturing industry will be interested in product and process innovation whereas service industry tends to do better in customer satisfaction.

\section{Hypothesis 11}

The result reported that the model is not different across length of reverse logistics implementation. Since there are fewer attractive results from implementing reverse logistics program, especially low level of cost savings. Thus, most of the companies do this program to some extent.

\section{Qualitative Results}

According to implementing reverse logistics will gain benefits in long term of economic, environmental, and social advantages. Most of the managers who emphasized on short term benefits did not see the increase in significant profits so they decided to ignore to implement. Meanwhile, some managers who comprehended long term benefits that reverse logistics program can assist to increase image and responsibility of company from customers' perception, led to high level of financial benefits. Because reverse logistics is associated with green logistics and ISO14000 qualification, thus, some companies determined to implement all of them. Unfortunately, these programs are less implemented due to voluntary program.

Considering high competition, the bargaining power of customers, global warming, and global conservation are important. Customers will judge and compare these factors among many firms then they easily decide to buy products or services from firms that they perceive more responsible towards earth problem. Therefore, companies need to take interest in these programs to survive in the long term. The legal and policy on environment and responsibility are less enforced than the developed countries as well as ASEAN countries such as Singapore, Malaysia, and Philippines. Thus, Thai government should focus more on details, motivations, mutual benefits between firms and country, legal punishments, and the strict enforcement of the law.

\section{RECOMMENDATIONS}

\section{Implications for Future Research}

The findings provide several implications for researchers. First, the results of this study supported past research, which suggests that sufficient and appropriate resources lead to more innovative results at lower cost, higher in operational improvement, customer responsiveness, and environmental and social responsibility. Second, results emerge from the existing body of reverse logistics enlightenment with confirmation of the mediate effect of size of firm and the time of company entrance to industry. Although, both models indicate two statistically significant estimations, however, both models confirm the influence of innovation.

Based on resource-based view, managerial and technology commitment are dynamic resources which are difficult to imitate whereas financial commitment assists operations to be smoothened. Third, managers understand the benefits of reverse logistics. Nevertheless the results of this study reported the low level of implication since they focus on only short term benefits. To gain more benefits, enthusiastic employees and balancing between short term and long term benefits is required. Finally, the results reported that managerial commitment is the most important factor, followed by financial and technological commitment respectively. Good management strategy conveys to higher profits which companies have enough money to invest in software, equipment, and systems.

\section{Implications for Practice}

The findings provide some implications for the organization. The result showed that resource commitment and reverse logistics innovation can enhance level of reverse logistics performance.

Thus, companies should emphasize more on suitable resource allocation and utilization, and approach to create innovation. In addition, an extremely proactive manner of executives is required in reverse logistics as well as reverse logistics should be realized as a challenge and not as an extra responsibility, issues, and trouble area. Moreover, the results of this study present that reverse logistics can be manipulated which can assist to acquire and gather sustainable competitiveness either in cost savings, operational improvement, customer responsiveness, and environmental and social responsibility. Though the reverse is ignored, it accounts for high proportion of GDP. Thus, the government should provide attractive return to implement reverse logistics program.

\section{LIMITATIONS OF THE STUDY}

Considering the potential limitations, some limitations were anticipated in this examination. The first limitation 
is the influence of exterior factors, which may involve resource commitment, reverse logistics innovation, reverse logistics performance, and reverse logistics cost savings such as macroeconomics and economic crisis. Second, due to the investigation applied self-report data and crosssectional data, the interference could not only make causal conclusion but also increase some anxieties about common bias.

Thus, a study in long term is needed to support better decisive interferences. The last limitation is the results describing activities and situations of companies in Thailand, which may not be according to foreign organizations.

\section{CONCLUSION}

Even though reverse logistics is one of the most interesting strategies in business companies and practitioners, an investigation in academic area is lacking (Veerakachen,
2006).

Due to the lack thereof at present time, it is probably to be a challenge for the anterior investigation to discover both dependent and independent factors, which lead to more comprehensions of the notions and utilizations. Moreover, the study in the future can extend to discover the feasible factors into the framework, which could be mediates and/or moderators, which can lead to greater comprehension about the sophisticated phenomena in the business firm associated with situation and issues of resource commitment, reverse logistics innovation, performance, and cost savings.

Lastly, the examination and the other supplementary studies in the future may carry on to investigate on how resource allocation and utilization could accumulate the reverse logistics innovation, which is the most valuable factor leading to reverse logistics and organizational success.

\section{REFERENCES}

Abdullah, N.A.H.N., \& Yaakub, S. 2014. Reverse logistics: Pressure for adoption and the impact on firm's performance. In- ternational Journal of Business \& Society, 15(1): 151-170.

Alshannag, F., Basah, M.Y.A., \& Khairi, K.F. 2017. The relationship between corporate social responsibility and corporate financial performance A survey of literature. International Journal of Business \& Administrative Studies, 3(1): 9-15. DOI: 10.20469 /ijbas.3.10002-1

Andel, T. 1997. Reverse logistics: A second chance to profit whether, through refurbishment or recycling, companies are finding profits in returned products. Transportation \& Distribution, 38(7): 61-64.

Autry, C.W., Daugherty, P.J., \& Glenn Richey, R. 2001. The challenge of reverse logistics in catalog retailing. International Journal of Physical Distribution \& Logistics Management, 31(1): 26-37. DOI: 10.1108/09600030110366384

Bagozzi, R.P. , \& Yi, Y. 1988. On the evaluation of structural equation models. Journal of the Academy of Marketing Science, 16(1): 74-94. DOI: $10.1007 / \mathrm{BF} 02723327$

Banomyong, R., Varadejsatitwong, P., \& Prakorbkij, P. 2005. Thailand's logistics cost per GDP. Unpublished doctoral disser- $\quad$ tation, Center for Logistic Research, Thammasat University, Bangkok, TH.

Barros, C.A.P., \& Santos, C.A. 2006. The measurement of efficiency in Portuguese hotels using data envelopment analysis. Journal of Hospitality \& Tourism Research, 30(3): 378-400. DOI: 10.1177/1096348006286798

Bentler, P. M., \& Bonett, D.G. 1980. Significance tests and goodness of fit in the analysis of covariance structures. Psycholog- ical Bulletin, 88(3): 588-591. DOI: 10.1037/0033-2909.88.3.588

Bentler, P. M., \& Chou, C.P. 1987. Practical issues in structural modeling. Sociological Methods \& Research, 16(1): 78-117. DOI: $10.1177 / 0049124187016001004$

Bentler, P. M. 1989. EQS structural equations program manual. Los Angeles, CA: BMDP Statistical Software. Browne, M.W., \& Cudeck, R. 1993. Alternative ways of assessing model fit. Sage Focus Editions, 154: 136-136. Cannon, J.P., \& Homburg, C. 2001. Buyer-supplier relationships and customer firm costs. Journal of Marketing, 65(1): 29- 43. DOI: $10.1509 /$ jmkg.65.1.29.18136

Chau, P.Y., \& Hu, P. J.H. 2001. Information technology acceptance by individual professionals: A model comparison approach. Decision Sciences, 32(4): 699-719. D0I: 10.1111/j.1540-5915.2001.tb00978.x

Christmann, P. 2000. Effects of best practices of environmental management on cost advantage: The role of complementary assets. Academy of Management Journal, 43(4): 663-680. DOI: 10.2307/1556360

Conant, J.S., Mokwa, M.P., \& Varadarajan, P. R. 1990. Strategic types, distinctive marketing competencies and organizational performance: A multiple measures-based study. Strategic Management Journal, 11(5): 365-383. 
DOI: $10.1002 /$ smj.4250110504

Council of Logistics Management. 1997. Council of logistics management. Israel, IL: Oak Brook.

Daugherty, P.J., Autry, C.W., \& Ellinger, A.E. 2001. Reverse logistics: The relationship between resource commitment and program performance. Journal of Business Logistics, 22(1): 107-123. DOI: 10.1002/j.2158-1592.2001.tb00162.x

Daugherty, P.J., Myers, M.B., \& Richey, R.G. 2002. Information support for reverse logistics: The influence of relationship commitment. Journal of Business Logistics, 23(1): 85-106. D0I: 10.1002/j.2158-1592.2002.tb00017.x

Dawe, R.L. 1995. Reengineer your returns. Transportation \& Distribution, 36(8): 78-80.

Decarlo, L.T. 1997. On the meaning and use of kurtosis. Psychological Methods, 2(3): 292-297.

DOI: $10.1037 / 1082-989 X .2 .3 .292$

Dekker, R., Fleischmann, M., Inderfurth, K., Van, W., \& Luk N. 2004. Reverse logistics: Quantitative models for closed-loop supply chains. New York, NY: Springer Science \& Business Media. DOI: 10.1007/978-3-540-24803-3

Delany, B. 2000. Eleventh annual state of logistics report St. Louis, MO: Cass logistics election. The Journal of Marketing

Channels, 11(4): 89-103.

Ettlie, J.E. 1983. Organizational policy and innovation among suppliers to the food processing sector. Academy of ManageJournal, 26(1): 27-44. DOI: 10.2307/256133

Fornell, C., \& Larcker, D.F. 1981. Evaluating structural equation models with unobservable variables and measurement er- ror. Journal of Marketing Research, 18(1): 39-50. DOI: 10.2307/3151312

Goodman, R.A., \& Abernathy, W.J. 1978. The contribution of new boy phenomena to increasing innovation and improve- ment in new technology. R\&D Management, 9(1): 33-42. DOI: 10.1111/j.1467-9310.1978.tb00130.x

Hair, J.R., Anderson, R.E., Tatham, R.L., \& Black, W.C. 1998. Multivariate data analysis. New Jersey, NJ: Prentice Hall In- ternational Inc.

Hart, S.L. 2005. Innovation creative destruction and sustainability. Research-Technology Management, 48(5): 21-27.

Hu, L.T., \& Bentler, P. M. 1999. Cutoff criteria for fit indexes in covariance structure analysis: Conventional criteria versus new alternatives. Structural Equation Modeling: A Multidisciplinary Journal, 6(1): 1-55.

DOI: $10.1080 / 10705519909540118$

Huang, Y.C., \& Yang, M.L. 2014. Reverse logistics innovation institutional pressures and performance. Management ReReview, 37(7): 615-641. DOI: 10.1108/MRR-03-2013-0069

Hunt, S.D., \& Morgan, R.M. 1996. The resource-advantage theory of competition: Dynamics path dependencies and evoludimensions. The Journal of Marketing, 60: 107-114. DOI: 10.2307/1251905

Hunt, S.D. 2000. A general theory of competition. Thousand Oaks, CA: Sage Publications.

Intan, W.S. 2016. The analysis factors of experential marketing product quality and customer satisfaction of motor bike as a main transportation mode in bandung-indonesia. International Journal of Business \& Administrative Studies, 2(1): 6-8. DOI: $10.20469 /$ ijbas.2.10002-1

Jack, E.P., Powers, T.L., \& Skinner, L. 2010. Reverse logistics capabilities: Antecedents and cost savings. International Jour- $\quad$ nal of Physical Distribution \& Logistics Management, 40(3): 228-246. DOI: 10.1108/09600031011035100 Jennings, D.F., \& Seaman, S.L. 1994. High and low levels of organizational adaptation: An empirical analysis of strategy structure, and performance. Strategic Management Journal, 15(6): 459-475. DOI: 10.1002/smj.4250150604 Jöreskog, K., \& Sörbom, D. 1996. LISREL 8: User's reference guide. Chicago, IL: Scientific Software International Inc. Judge, W. Q., \& Douglas, T. J. 1998. Performance implications of incorporating natural environmental issues into the strateplanning process: An empirical assessment. Journal of Management Studies, 35(2): 241-262.

DOI: $10.1111 / 1467-6486.00092$

Kaplan, R.S., \& Norton, D.P. 2001. The strategy-focused organization. Strategy \& Leadership, 29(3): 41-42.

DOI: $10.1108 / \mathrm{sl} .2001 .26129 \mathrm{cab} .002$

Kumar, S., \& Yamaoka, T. 2007. System dynamics study of the Japanese automotive industry closed loop supply chain.

Jour- $\quad$ nal of Manufacturing Technology Management, 18(2): 115-138. DOI: 10.1108/17410380710722854

Kuo, M.P., \& Chen, Y.M. 2015. A Study on the relationships among body sensory experience, customer satisfaction and cus- $\quad$ tomer loyalty-Beauty SPA center as an example. International Journal of Business \& Administrative Studies, 1(2): 
61-67. DOI: 10.20469/ijbas.10003-2

Laitinen, E.K. 2002. A dynamic performance measurement system: Evidence from small Finnish technology companies.

Scandinavian Journal of Management, 18(1): 65-99. D0I: 10.1016/S0956-5221(00)00021-X

Li, X., \& Olorunniwo, F. 2008. An exploration of reverse logistics practices in three companies. Supply Chain Management:

An International Journal, 13(5): 381-386. DOI: 10.1108/13598540810894979

Li, Z., Zhang, M., Zhang, X., Dai, S., Yu, X., \& Wang, Y. 2009. Assessment of cerebral oxygenation during prolonged simulated driving using near infrared spectroscopy: Its implications for fatigue development. European Journal of Applied Phys- iology, 107(3): 281-287. D0I: 10.1007/s00421-009-1122-6

Lynch, R., \& Cross, K. 1991. Measure up yardsticks for continuous improvement. Cambridge, MA: Basil Blackwell Inc.

Minahan, T. 1998. Enterprise resource planning: Strategies not included. Purchasing, 125(1): 112-127.

Naqshbandi, M.M. 2016. Managerial ties and open innovation: Examining the role of absorptive capacity, Management De- cision, 54(9): 2256-2276.

Naqshbandi, M.M., \& Kaur, S. 2014. Theories in innovation management selected theories in social sciences. Kuala

Lumpur, KL: UM Press.

Naqshbandi, M.M., Kaur, S., \& Ma, P. 2015. What organizational culture types enable and retard open innovation? Quality \& Quantity, 49(5): 2123-2144.

Naqshbandi, M.M., \& Kaur, S. 2011a. Effects of managerial ties and appropriability regimes on open innovation. World Ap- plied Sciences Journal, 15(2): 271-278.

Naqshbandi, M.M., \& Kaur, S. 2011b. Factors affecting Open Innovation: Evidence from Malaysia. Australian Journal of

Basic \& Applied Sciences, 5(12): 2783-1795.

Naqshbandi, M.M., \& Kaur, S. 2015. Effectiveness of innovation protection mechanisms in Malaysian high-tech sector. Manment Research Review, 38(9): 952-969.

Otley, D. 1999. Performance management: A framework for management control systems research. Management AccountResearch, 10(4): 363-382. DOI: 10.1006/mare.1999.0115

Pfohl, H.C., Bode, A., \& Nguyen, T. 2012. Adaptability to reverse logistics-An empirical study in European electronics indusJournal of Global Strategic Management, 11(6): 89-101. DOI: 10.20460/JGSM.2012615789

Piyachat, B., Chanongkorn, K., \& Panisa, M. 2014. The mediate effect of employee engagement on the relationship between perceived employer branding and discretionary effort. Business \& Economics Review, 24(1): 34-40.

Prahinski, C., \& Kocabasoglu, C. 2006. Empirical research opportunities in reverse supply chains. Omega, 34(6): 519-532.

DOI: $10.1016 /$ j.omega.2005.01.003

Pugh, D.S., Hickson, D.J., Hinings, C.R., \& Turner, C. 1968. Dimensions of organization structure. Administrative Science Quarterly, 2(4): 65-105. DOI: 10.2307/2391262

Ramírez, A.M., \& Morales, V.J.G. 2014. Improving organisational performance through reverse logistics. Journal of the Op- erational Research Society, 65(6): 954-962. DOI: 10.1057/jors.2013.61

Rennings, K. 2000. Redefining innovation-Eco-innovation research and the contribution from ecological economics. Eco- Iogical Economics, 32(2): 319-332. DOI: 10.1016/S0921-8009(99)00112-3

Reverse Logistics Executive Council. 2007. Glossary. URL: goo.gl/kMwsBo

Richey, R.G., Chen, H., Genchev, S.E., \& Daugherty, P.J. 2005. Developing effective reverse logistics programs. Industrial Mar- $\quad$ keting Management, 34(8): 830-840. DOI: 10.1016/j.indmarman.2005.01.003

Richey, R.G., Daugherty, P.J., Genchev, S.E., \& Autry, C.W. 2004. Reverse logistics: The impact of timing and resources. Jour- $\quad$ nal of Business Logistics, 25(2): 229-250. D0I: 10.1002/j.2158-1592.2004.tb00188.x

Rogers, D.S., \& Tibben-Lembke, R.S. 1998. Going backwards: Reverse logistics trend and practices. Pittsburgh, PA: Re- verse Logistics Executive Council Press.

Sarkis, J., Helms, M.M., \& Hervani, A.A. 2010. Reverse logistics and social sustainability. Corporate Social Responsibility \&

Environmental Management, 17(6), 337-354. DOI: 10.1002/csr. 220

Shear, H., Speh, T., \& Stock, J. 2002. Many happy (product) returns. Harvard Business Review, 80(7): 16-17.

Sink, D.S., \& Tuttle, T. C. 1989. Planning and measurement in your organization of the future. Norcross, GA: IE Press. Srivastava, S.K., \& Srivastava, R.K. 2006. Managing product returns for reverse logistics. International Journal of Physical 
Distribution \& Logistics Management, 36(7): 524-546. D0I: $10.1108 / 09600030610684962$

Stuart, A., \& Ord, J.K. 1994. Kendall's advanced theory of statistics. London, UK: Edward Arnold.

Veerakachen, V. 2006. Reverse logistics performance in the Thai automotive industry. Unpublished doctoral disserta- tion, Thammasat University, Bangkok, TH.

Weston, R., \& Gore Jr, P.A. 2006. A brief guide to structural equation modeling. The Counseling Psychologist, 34(5): 719- 751. DOI: $10.1177 / 0011000006286345$

Wright, S. 1921. Correlation and causation. Journal of Agricultural Research, 20(7): 557-585.

$\mathrm{Wu}$, P. J. 2016. Logistics business analytics for achieving environmental sustainability. Journal of Administrative \& Busi- ness Studies, 2(6): 264-269. DOI: 10.20474/jabs-2.6.1

— This article does not have any appendix. - 